\title{
Defining ruminal and total-tract starch degradation for adult dairy cattle using in vivo data
}

\author{
R. A. Patton, ${ }^{\star 1}$ J. R. Patton, ${ }^{\star}$ and S. E. Boucher† \\ *Nittany Dairy Nutrition Inc., Mifflinburg, PA 17844 \\ †Kemin AgriFoods North America, Des Moines, IA 50306
}

\begin{abstract}
Literature was searched for studies performed in adult dairy cattle that simultaneously measured starch degradability in the rumen (RSDeg) and starch digestion in the total tract to compute postruminal starch digestion (PRSDig). Forty-one studies with 161 dietary treatments were used to form the data set. Of these diets, the major starch source was corn for 83 diets, small grain for 58 diets, and sorghum for 8 diets. Corn RSDeg was more variable than other sources. As measured in vivo across all starch sources, the percent RSDeg was influenced only by the amount of starch consumed, with the amount of degradation being approximately $75 \%$ at low starch intakes and decreasing to about $60 \%$ when $4 \mathrm{~kg}$ or more of starch were consumed. Small grain starch had greater RSDeg than corn or sorghum starch, which were approximately equal. The PRSDig of corn and small grain starches were approximately equal, but sorghum was about $15 \%$ less. Across all diets, models derived from the Cornell Net Carbohydrate Protein System predicted percentage of totaltract digestibility of starch very accurately, but overpredicted RSDeg and, as a result, underpredicted percent PRSDig. Calculation of RSDeg using a French model predicted the mean RSDeg with greater accuracy but less precisely. The relative differences in RSDeg percent among starch sources was correctly predicted by these models. A model using a revised rate of digestion as a way of combining effects of starch type and processing was developed, which predicted corn starch RSDeg and PRSDig with greater accuracy than nutrition models but only slightly better than using the mean observed degradation or the French calculation. Inaccuracies in prediction of RSDeg may be due mainly to processing effects and particle sizes, but these were not well reported in literature studies and were difficult to estimate. More accurate assessment of RSDeg and PRSDig will
\end{abstract}

Received January 17, 2011.

Accepted September 30, 2011.

${ }^{1}$ Corresponding author: nittnut@aol.com require better and more consistent reporting of grain processing. Based on this study, the French calculation is the most accurate of the models examined, although adjustments will be required to improve accuracy.

Key words: ruminal starch degradation, postrumen digestion, total-tract starch digestion

\section{INTRODUCTION}

Dairy cattle consume large amounts of starch (20-40\% of diet DM) as a way to increase energy consumption in support of high milk production. Accurate prediction of the amount of ruminal starch degradability (RSDeg) is critical for accurate prediction of ruminal microbial protein production as well as the amount and types of VFA presented for absorption (Stern and Hoover, 1979). At present, most ruminant nutrition models that predict RSDeg use a version of the equation suggested by Ørskov and McDonald (1979), where the RSDeg = weight of immediately disappearing fraction + weight of potentially degradable fraction $\times[\mathrm{kd} /(\mathrm{kd}+\mathrm{kp})]$, where $\mathrm{kd}=$ rate of digestion and $\mathrm{kp}=$ rate of passage, and $\mathrm{kd}$ and $\mathrm{kp}$ are expressed as percentage per hour. Rate of digestion for individual starch sources is defined by in situ incubations using Dacron bags. Methodology for in situ starch determinations, including bag pore size, grind size, and incubation times, have been rigorously defined (Nocek, 1988). Although this methodology provides reproducible kd numbers, it has been noted that estimates of RSDeg produced by the in situ technique do not closely match in vivo estimates (Mills et al., 1999).

Starch digestion in cattle and the many factors that affect it have been reviewed (Nocek and Tamminga, 1991; Mills et al., 1999; Firkins et al., 2001; Owens, 2005). Nocek and Tamminga (1991) published estimates of RSDeg based on the kd from in situ studies, including data from all ruminant species, and suggested that this was reasonably well correlated to in vivo starch degradability $\left(\mathrm{R}^{2}=0.65\right)$. These authors also concluded that the variability of RSDeg was high and that the amount of starch consumed had little effect on 
degradability. Firkins et al. (2001) summarized in vivo RSDeg in dairy cattle, as well as the effect that processing methods had on both total-tract starch digestion (TT) and milk production response to high-starch feeds. However, Firkins et al. (2001) estimated starch degradation and content from NFC data, which may have led to inaccurate prediction of chemically defined starch. These authors reported that postruminal starch digestion (PRSDig) was negatively affected by dietary NDF content and DMI and concluded that more rigorous processing increased both RSDeg and PRSDig. Nocek and Tamminga (1991) and Firkins et al. (2001) all concluded that as the percent of starch undegraded in the rumen increased, a greater percent of starch digestion occurred in the small intestine, resulting in little overall difference in total-tract digestion. Offner et al. (2003) also reported starch degradation based on in situ data, but only from experiments where it was determined in bovine species. In later studies Offner and Sauvant (2004) confirmed the previously reported effects of processing and intake. They also determined that RSDeg determined in situ were approximately 20 to $40 \%$ higher than those measured in vivo and offered regressions for calculating in vivo RSDeg from in situ values. Reynolds (2006) suggested that PRSDig is energetically more efficient than RSDeg, but that this efficiency occurs at the expense of microbial protein formation. For high-producing or early lactation cows where DMI is limited, he suggested that a diet with low RSDeg may have production advantages because of greater overall energy availability. Models based on the Cornell Net Carbohydrate Protein System (CNCPS) have been developed to predict both RSDeg and PRSDig (Sniffen et al., 1992; Tylutki et al., 2008) and have been incorporated into dairy ration software [Cornell-Penn-Miner (CPM) Dairy version 3.0.10, Cornell University (Ithaca, NY), University of Pennsylvania (Philadelphia), The William H. Miner Agricultural Research Institute (Chazy, NY), and the University of Maryland (College Park) cooperating; software by Agricultural Modeling and Training Systems (AMTS) LLC, Cortland, NY]. However, to our knowledge, predicted amounts of RSDeg and PRSDig from these models have not been compared with data measured in vivo.

Therefore, the objectives of this study were (1) to identify factors affecting RSDeg and PRSDig for various feedstuffs using in vivo studies; (2) to compare in vivo observations of RSDeg and PRSDig in published studies with model estimates provided by CPM, AMTS, and a model suggested by Offner and Sauvant (2004); and (3) to investigate other methods of predicting RSDeg and PRSDig, comparing these with in vivo observations.

\section{MATERIALS AND METHODS}

\section{Data Sources}

The Google Scholar and Agricola electronic databases were scanned to identify studies where RSDeg and PRSDig had been measured simultaneously in lactating cattle fitted with both ruminal and duodenal cannulas and using marker techniques. Starch content was determined by different methods (Aman and Hesselman, 1984; Karkalas, 1985; Herrera-Saldana et al., 1990; Faisant et al., 1995), but each involved solubilization of starch and measurement of released glucose. Studies reporting digestibility of NFC or water-soluble carbohydrate without reporting a pure starch fraction were not used. Likewise, studies that reported dietary RSDeg determined only by in situ methods were not used because starch was not chemically defined. Mean dietary composition from each diet in each study was entered into the database at the reported treatment mean DM consumption. When nutrient composition of ingredients was reported in the study, this data was recorded in the database. When only the total dietary composition was provided, nutrient values (other than for starch) were taken from the National Research Council (NRC, 2001) and were used as a starting point, but were adjusted to agree with the reported dietary percentage of NDF, CP, RDP, RUP, neutral detergentinsoluble crude protein (NDICP), acid detergentinsoluble crude protein (ADICP), and lignin, as well as fat and ash, all on a DM basis. Individual feeds were not varied by more than $15 \%$ of the default value. If starch content of an ingredient was not reported, starch data from the CPM v.3.0.10 feed library was used for this ingredient. These values were also adjusted to agree with starch levels reported in the total diet. In almost all studies, the starch content of major sources was reported. Therefore, starch values from CPM were used only for ingredients contributing minor amounts of starch to the diet. The other default values were taken from the NRC because this is the most widely accepted database and most published diets would be evaluated with these values. Similarly, unknown starch values were taken from CPM because it contains a widely recognized starch database. Because different models were evaluated, the goal was to standardize data entered into the models, so that methods of calculating RSDeg were compared without the confounding influence of different database starch contents.

\section{Determination of RSDeg and PRSDig Regressions}

The DM amount of each ingredient in the ration was multiplied by the percentage of starch contained as 
determined on a DM basis to determine the starch contributed by each feed. Within each ration, the weight of starch in individual ration components was then summed, and this was taken as the observed weight of starch consumed. The weight of starch reported in the study to be degraded in the rumen was divided by the DMI and multiplied by 100 to calculate a percent RSDeg as

RSDeg $=$ weight of starch degraded in rumen

$(\mathrm{DM}) /$ weight of starch consumed $(\mathrm{DM}) \times 100$. [1]

The amount of starch degraded in the rumen was then subtracted from the amount of starch reported to be digested in the total tract. This difference was taken as the amount of starch digested postruminally, which was then divided by the weight of starch consumed to determine the PRSDig as

PRSDig $=$ weight digested postruminally

$(\mathrm{DM}) /$ weight of starch consumed $(\mathrm{DM}) \times 100$. [2]

Dietary factors evaluated for possible effects on RSDeg and PRSDig were DM of ingredient, NDF, lignin, CP, RDP, RUP, NDICP, ADICP, NFC, starch, sugar, ash, and crude fat, all on percentage of DM basis, as well as the amount of each of these nutrients consumed. Also evaluated were cow factors such as BW, milk production, milk fat percentage, milk CP percentage, DIM, DMI, percentage of diet that was forage, percentage of $\mathrm{NDF}$ that was forage NDF, as well as rumen $\mathrm{pH}$ when it was reported. Regressions for determining significant correlations to RSDeg and PRSDig were performed in SAS (version 8; SAS Institute Inc., Cary, NC) using stepwise elimination. Regressions were also performed using the same inputs for starch sources within processing effects using PROC REG with stepwise elimination. For the regression graph of the effect of starch intake, the significant regression equation for kilograms of RSDeg was used to predict the kilograms of starch degraded, and that degraded starch amount converted to percentage of starch degraded.

\section{Model Inputs}

Diet and ingredient compositions determined as described above were entered into the CPM Dairy model with feed selection matching identified processing effects to the extent possible. The following model outputs were recorded: DMI, starch as percentage of diet DM, and kilograms of starch fermented in the rumen. For CPM, predicted PRSDig was calculated as total starch consumed less the model-predicted starch degraded in the rumen multiplied by the model-calculated postruminal starch digestibility:

$$
\begin{gathered}
\text { PRSDig }_{\mathrm{CPM}}=(\text { starch consumed }- \text { rumen-degraded } \\
\text { starch }) \times \text { postruminal starch digestion }(\%) .
\end{gathered}
$$

The CPM rations were uploaded into the AMTS model of the Cornell Net Carbohydrate Protein System and similar outputs recorded. Model degradation rates $(\mathrm{kd})$ and intestinal digestion coefficients were not modified from default values in either program.

The model designated OFF was calculated from Offner and Sauvant (2004) with the kd of various feedstuffs taken from Offner et al. (2003) and applied to the following equations to predict RSDeg:

$$
\text { RSDeg }=0.439+0.68 \times \text { effective degradability, }[4]
$$

where

$$
\text { effective degradability }=\Sigma \text { pi } \times \text { EDi }
$$

and pi $\times \mathrm{EDi}=$ the effective starch degradability of each ingredient as determined by the Ørskov and McDonald (1979) formula described previously and with $\mathrm{kp}$ calculated for forage and concentrate (Offner and Sauvant, 2004) as

$$
\begin{gathered}
\mathrm{kp}_{\text {forage }}=0.021+0.007 \times \mathrm{DMI}, \text { percentage of BW, }[6] \\
\mathrm{kp}_{\text {concentrate }}=0.018+0.014 \times \mathrm{DMI}, \\
\text { percentage of } \mathrm{BW} .
\end{gathered}
$$

Because Offner et al. (2003) did not report starch kd data for all feeds in the data set, the following substitutions for $\mathrm{kd}$ were used: the corn silage $\mathrm{kd}$ value was used for barley silage; the soybean meal kd was used for canola meal; alfalfa $\mathrm{kd}$ was used for grasses, and the $k d$ value for peas was used for whole linseeds. Data were calculated assuming no immediately degradable fraction (Offner and Sauvant, 2004). Data recorded included starch intake, starch degraded in the rumen, and starch digested in the total tract. The RSDeg and PRSDig were recorded as described earlier.

The accuracy of model predictions was tested against observed TT, RSDeg, and PRSDig by various methods including regression of observed values on predicted values, specifying coefficient of determination, intercept, and slope parameters as described by Pacheco et al. (2006). Also used were the mean square prediction error (MSPE), root mean square error (RMSE) as 
percent of observed mean, and the decomposition of the MSPE into mean bias, regression error, and random error, as described by Bibby and Toutenburg (1977). All statistics were performed with version 8 of SAS.

\section{Development of Alternative Models}

In an attempt to improve on existing prediction of TT, RSDeg, and PRSDig, alternative methods for calculating these values were developed. A mean value for these estimates was calculated. Also, 2 different attempts were made to develop alternative kd values, as well as estimates derived from simple regression of total-tract digestibility, both across and within starch sources. These approaches are described in detail below.

\section{Development of Simple Mean Model}

Simple means of RSDeg and PRSDig for individual ingredients were calculated from in vivo data using the following technique. After observed RSDeg and PRSDig had been adjusted for the effects of study (StPierre, 2001), individual RSDeg and PRSDig of each feed were estimated by assuming that starch in other dietary ingredients was either totally digested or alternatively, not digested at all. This made possible the calculation of the highest possible starch degradation (i.e., the starch in other ingredients was indigestible, and all of the reported digested starch must come from the ingredient under consideration) and the lowest possible starch digestion (i.e., the starch in the other dietary ingredients was totally digestible, and only the last portion of the digested starch was contributed by the ingredient under consideration). A sample calculation is included in Appendix 1. At least 1 ingredient had to represent more than $50 \%$ of the total starch consumed for a diet to be evaluated by this technique. Additionally, all calculations were constrained so that the highest amount of starch degraded or digested was $99.9 \%$, and the lowest amount was $0.1 \%$. Two starch degradability and digestibility values were recorded for each ingredient in each ration of each study as the minimum and the maximum possible. The average of these values was calculated as the RSDeg and PRSDig for each feed. Finally, a mean of all ingredients of 1 type was calculated with the standard error reported as the standard error of the mean. These calculated means of RSDeg and PRSDig were applied to each ration, and these rations (simple mean, SM, model) were analyzed by the statistical methods described above.

\section{Development of the Revised kd Model}

Rates of passage were determined for OFF by the method described in Offner and Sauvant (2004), Cha- lupa et al. (1991), Seo et al. (2006), and NRC (2001) to select an appropriate $\mathrm{kp}$ for development of a revised kd (rkd) model for use in the Ørskov and McDonald (1979) equation. After examination, the OFF $\mathrm{kp}$ was selected to calculate a revised $\mathrm{kd}$ for each feed in each ration by the rearrangement of the Ørskov and McDonald (1979) formula as

$$
\mathrm{kd}=\mathrm{R}-\mathrm{kp} /(\mathrm{S}-\mathrm{R}),
$$

where $\mathrm{S}=$ starch amount, $\mathrm{R}=$ the amount of starch degraded, and kp was calculated as above. Starch digested for each feed was as determined by the simple mean method described previously. A second ingredient kd was determined as the percent of starch digestion reported for each ration multiplied by the starch content of each ingredient. Then, the individual $\mathrm{kd}$ values were grouped by feed, and the means of these calculations were designated as the rkd for each feed. An RSDeg was calculated in all rations using the mean rkd by the equation of Ørskov and McDonald (1979). A revised PRSDig was calculated for each feed by subtracting the revised RSDeg for each feed from the TT as predicted by the mean method described above. This model was also analyzed by the same statistical methods for models described before.

\section{Investigations into Other Approaches}

Other approaches to produce better estimates of RSDeg and PRSDig were attempted. These included regression of RSDeg from the observed TT digestion, both across and within starch type with and without processing factors included. Also attempted was regression from the amount of starch consumed and a revised kd based on the average RSDeg and PRSDig reported in each study.

\section{RESULTS AND DISCUSSION}

\section{Effects on Observed Results}

Forty-one studies and 161 dietary treatment means were identified that met the established criteria. References for these studies are included in Appendix 2, and simple descriptive statistics including dietary factors are presented in Table 1. In these diets, corn made up the major starch source in 82 diets, small grain was the major source in 58 diets, whereas sorghum was the major starch source in 8 diets. Corn starch sources included corn grain of various processing methods, corn silage, and feed grade corn starch. Small-grain starch sources were both barley and wheat grains processed in various ways, whereas sorghum was entirely sorghum 
Table 1. Descriptive statistics for diets used in evaluation of ruminal starch degradation and total-tract starch digestion

\begin{tabular}{lccccc}
\hline Variable & $\mathrm{n}$ & Mean & \pm SE & Minimum & Maximum \\
\hline BW, kg & 161 & 617 & 54 & 410 & 690 \\
DIM & 158 & 138 & 52 & 28 & 274 \\
Milk, kg/d & 140 & 29.2 & 6.5 & 13.0 & 42.5 \\
Milk fat, \% & 140 & 3.60 & 0.40 & 2.67 & 4.61 \\
Crude milk protein, \% & 140 & 3.14 & 0.20 & 2.62 & 3.86 \\
DMI, kg/d & 161 & 20.3 & 3.2 & 9.1 & 26.8 \\
Forage, \% of DM & 161 & 47.0 & 11.0 & 23.0 & 90.0 \\
Rumen pH & 121 & 6.13 & 0.28 & 5.60 & 6.90 \\
CP, \% of DM & 161 & 17.5 & 2.3 & 11.6 & 26.2 \\
NDF, \% of DM & 161 & 32.3 & 6.8 & 20.7 & 65.3 \\
Sugar, \% of DM ${ }^{2}$ & 161 & 4.3 & 2.4 & 1.2 & 12.9 \\
Crude fat, \% of DM & 161 & 4.05 & 1.34 & 1.30 & 7.37 \\
Starch, \% of DM & 161 & 25.2 & 8.0 & 0.7 & 39.7 \\
Starch, kg/d consumed & 161 & 5.17 & 1.9 & 0.13 & 9.14 \\
Starch, kg reported degradable in rumen & 161 & 3.141 & 1.368 & 0.01 & 6.432 \\
Starch, kg reported digestible in total tract & 161 & 1.650 & 1.255 & 0.03 & 4.841 \\
19stimated assuming that corn silage was 100\% forage. & & &
\end{tabular}

grain, either steam flaked or ground. Mean observed RSDeg, PRSDig and TT for these feed classes are presented in Table 2.

Across all feeds, correlation between starch consumed and kilograms of RSDeg, kilograms of PRSDig, and kilograms of TT was high (Table 3), although no significant regression was observed for percentage of these factors. The relationship of RSDeg and intake is summarized across all diets in the regression plot in Figure 1. Across all diets, RSDeg was high ( 75\%) at low starch intakes, and it appeared to plateau at about $60 \%$ for starch consumption over $4 \mathrm{~kg}$ per day. Contrary to the reports of Firkins et al. (2001) and Offner et al. (2003), this in vivo data provided no indication of an effect of DMI on percentage or amount of RSDeg. In fact, 2 studies looked at this directly and in detail (Doreau et al., 1990; Volden, 1999). That is, they fed the same diet to the same cows at different stages of lactation when DMI was different. The mean RSDeg of low-intake cows $(11.9 \pm 3.0 \mathrm{~kg} / \mathrm{d})$ was $84.0 \pm 8.9 \%$ compared with higher-intake cows $(17.7 \pm 0.3 \mathrm{~kg} / \mathrm{d})$, which was $85.0 \pm 8.4 \%$, a nonsignificant difference. In the present study, no effect of dietary constituents across all feeds, including NDF and RDP, on RSDeg or PRSDig, and no cow effects such as BW were found, which is different than reported by Firkins et al. (2001). For corn starch sources, sugar as percent DM was a significant factor for percent PRSDig and kilograms of PRSDig. For small grains, percent forage in the diet was also a significant factor, although the overall coefficient of determination was low. No significant regression equations for sorghum were identified, although the numbers of diets were few. Regression analyses were performed for individual starch sources and processing types where identified. For high-moisture corn, steam-processed corn, corn silage, all small grains, and sorghum, DMI did not enter into a significant equation. Only in the cases of cracked corn $(\mathrm{n}=3$ diets) and ground corn ( $\mathrm{n}=46$ diets) was a term for DMI or DMI as percentage of BW significant for RSDeg (data not shown). For this data set, it appears that the amount of starch consumed is the only meaningful modifier of RSDeg. The lack of a large DMI effect on either RSDeg or PRSDig, coupled with the observations cited for the studies of Doreau et al. (1990) and Volden (1999), suggest that the rate of passage per se did not have a large effect on RSDeg as measured in vivo. This agrees in principle with the study by Hall (2004).

In this study, the standard error of TT between corn and small grains was not greatly different (Table 3),

Table 2. Observed mean percent starch digestion and degradation in studies used to evaluate starch utilization

\begin{tabular}{|c|c|c|c|c|c|c|c|}
\hline \multirow{2}{*}{$\begin{array}{l}\text { Feed } \\
\text { type }\end{array}$} & \multirow[b]{2}{*}{$\mathrm{n}$} & \multicolumn{2}{|c|}{ Total tract } & \multicolumn{2}{|c|}{ Rumen } & \multicolumn{2}{|c|}{ Postrumen } \\
\hline & & Mean & $\pm \mathrm{SE}$ & Mean & $\pm \mathrm{SE}$ & Mean & $\pm \mathrm{SE}$ \\
\hline All & 161 & 92.8 & 7.4 & 61.8 & 20.6 & 30.9 & 19.2 \\
\hline Corn & 82 & 92.3 & 6.2 & 54.6 & 18.5 & 37.7 & 17.7 \\
\hline Small grain & 58 & 94.6 & 5.4 & 76.4 & 15.4 & 18.2 & 13.0 \\
\hline Sorghum & 8 & 80.4 & 17.7 & 54.0 & 17.5 & 26.3 & 12.7 \\
\hline
\end{tabular}




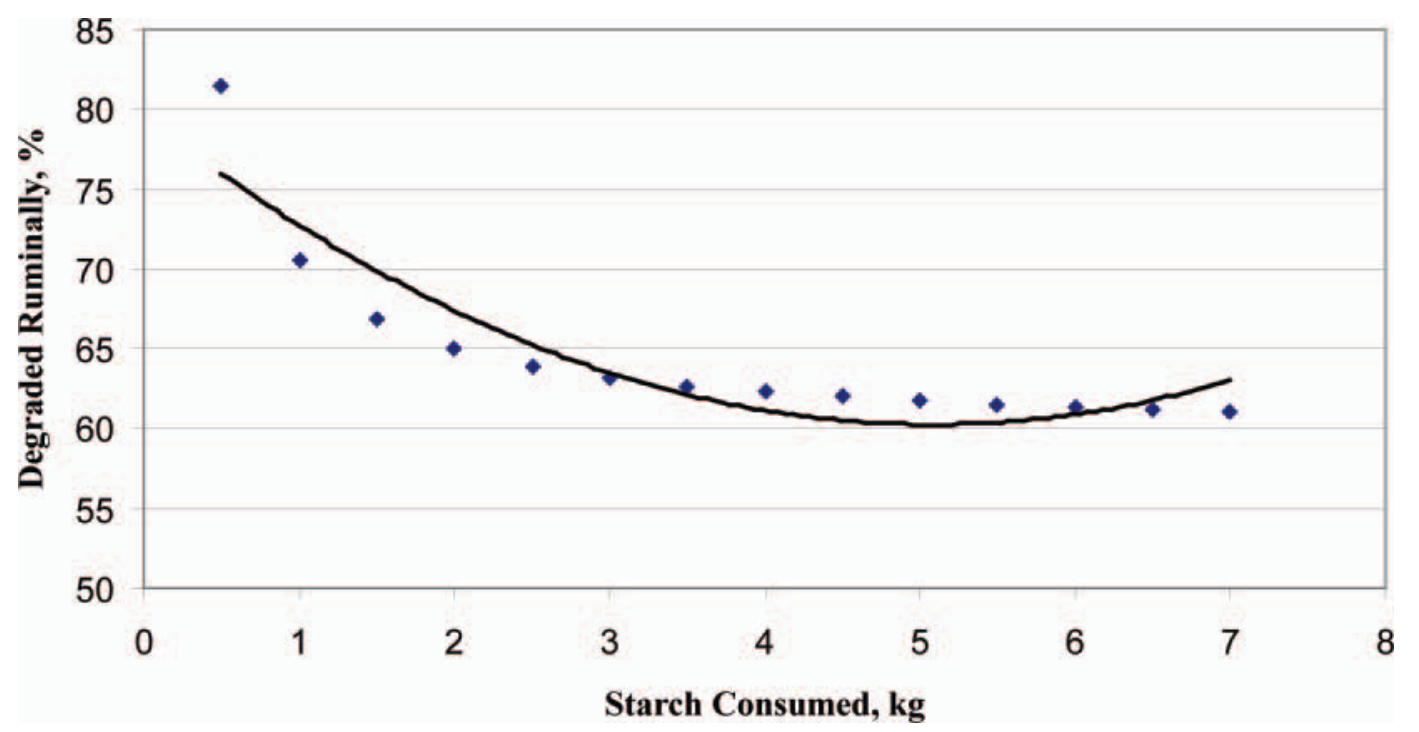

Figure 1. Regression plot across all diets for effect of amount of starch consumed on percent ruminal starch degradation from equation: starch degraded $=0.0357+0.6000 \mathrm{~kg}$ of starch consumed, $\left(\mathrm{R}^{2}=0.87\right)$ and these amounts converted to percentage of starch consumed. Color version available in the online $\mathrm{PDF}$.

which was contrary to the study of Firkins et al. (2001). Across all diets, after correcting for the effects of study, mean percent RSDeg was $61.8 \pm 20.6 \%$, mean percent PRSDig was $30.9 \pm 19.2 \%$, and mean percent TT was $92.8 \pm 7.4 \%$. The smaller standard errors for TT compared with RSDeg and PRSDig suggest that the combi- nation of starch degradation and digestion is relatively constant for a given feed, although the location may shift between rumen and postrumen. This also suggests that different levels of processing of the grain source may provide a partial explanation for the variability of RSDeg. These observations are in agreement with

Table 3. Significant regression equation for ruminal degradation (RSDeg), postruminal digestion (PRSDig), and total-tract starch digestion (TT) for various feed types, both as percent and by weight

\begin{tabular}{|c|c|c|}
\hline $\begin{array}{l}\text { Starch } \\
\text { type }\end{array}$ & Equation & $\mathrm{R}^{2}$ \\
\hline \multirow[t]{4}{*}{ All feeds } & $\begin{array}{l}\% \text { RSDeg }=\mathrm{NSE}^{1} \\
\% \text { PRSDig = NSE } \\
\% \mathrm{TT}=\mathrm{NSE}\end{array}$ & \\
\hline & $\mathrm{kg}$ of RSDeg $=0.1092+(0.5956 \times \mathrm{kg}$ of starch consumed $)$ & 0.84 \\
\hline & $\mathrm{kg}$ of PRSDig $=-0.070+(0.321 \times \mathrm{kg}$ of starch consumed $)$ & 0.70 \\
\hline & $\mathrm{kg}$ of $\mathrm{TT}=-0.0695+(0.3211 \times \mathrm{kg}$ of starch consumed $)$ & 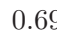 \\
\hline \multirow{4}{*}{ Corn grain } & $\%$ RSDeg $=55.34+(1.40 \times$ sugar $\% \mathrm{DM})$ & 0.10 \\
\hline & $\mathrm{kg}$ of RSDeg $=0.3405+(0.5455 \times \mathrm{kg}$ of starch consumed $)$ & 0.73 \\
\hline & $\mathrm{kg}$ of PRSDig $=0.319+(0.313 \times \mathrm{kg}$ of starch consumed $)-(0.081 \times$ sugar, $\% \mathrm{DM})$ & 0.64 \\
\hline & $\mathrm{kg}$ of $\mathrm{TT}=-0.3184+(0.3712 \times \mathrm{kg}$ of starch consumed $)$ & 0.64 \\
\hline \multirow[t]{2}{*}{ Small grain } & $\begin{array}{l}\% \text { RSDeg }=61.406+(0.153 \times \text { starch } \% \text { DM }) \\
\% \text { PRSDig }=\text { NSE }\end{array}$ & 0.05 \\
\hline & $\% \mathrm{TT}=99.25-(0.1145 \times$ forage $\% \mathrm{DM})$ & 0.15 \\
\hline & $\begin{array}{l}\% \mathrm{TT}=\mathrm{NSE} \\
\mathrm{kg} \text { of } \mathrm{RSDeg}=\mathrm{NSE}\end{array}$ & \\
\hline & $\mathrm{kg}$ of PRSDig = NSE & \\
\hline & $\mathrm{kg}$ of $\mathrm{TT}=\mathrm{NSE}$ & \\
\hline
\end{tabular}

\footnotetext{
${ }^{1} \mathrm{NSE}=$ no significant equation.
} 
Table 4. Comparisons of existing models for starch digestion on a percentage basis across all sources in adult dairy cows

\begin{tabular}{|c|c|c|c|c|c|}
\hline Site & Parameter $^{1}$ & Observed & \multicolumn{3}{|c|}{ Model $^{2}$} \\
\hline \multirow{7}{*}{ Total tract } & Mean & 92.8 & 96.0 & 96.3 & 92.9 \\
\hline & Linear regression & & $\mathrm{y}=-75.3+1.75 \mathrm{x}$ & $\mathrm{y}=-37.1+1.35 \mathrm{x}$ & $\mathrm{y}=0.1+0.99 \mathrm{x}$ \\
\hline & $\mathrm{R}^{2}$ & & 0.83 & 0.78 & 0.72 \\
\hline & MSPE & & 9.09 & 11.95 & 14.95 \\
\hline & Mean bias, $\%$ & & 18.8 & 22.0 & 3.1 \\
\hline & Regression error, \% & & 1.9 & 0.4 & 4.4 \\
\hline & Random error, \% & & 79.3 & 77.6 & 92.5 \\
\hline \multirow[t]{5}{*}{ Rumen } & Mean & 61.8 & 81.2 & 82.4 & 64.9 \\
\hline & $\pm \mathrm{SE}$ & 20.6 & 6.6 & 6.9 & 8.1 \\
\hline & Linear regression & & $y=8.7+0.65 x$ & $\mathrm{y}=27.7+0.41 \mathrm{x}$ & $\mathrm{y}=-27.9+1.38 \mathrm{x}$ \\
\hline & $\mathrm{R}^{2}$ & & 0.77 & 0.76 & 0.83 \\
\hline & Random error, $\%$ & & 48.7 & 46.1 & 89.4 \\
\hline \multirow[t]{10}{*}{ Postrumen } & Mean & 30.9 & 14.8 & 14.0 & 27.8 \\
\hline & $\pm \mathrm{SE}$ & 19.2 & 4.8 & 5.1 & 5.3 \\
\hline & Linear regression & & $\mathrm{y}=32.2-0.08 \mathrm{x}$ & $\mathrm{y}=37.5-0.46 \mathrm{x}$ & $\mathrm{y}=-4.4+1.27 \mathrm{x}$ \\
\hline & $\mathrm{R}^{2}$ & & 0.79 & 0.80 & 0.81 \\
\hline & MSPE & & 76.09 & 71.66 & 67.12 \\
\hline & RMSE, \% mean & & 28.2 & 27.4 & 26.5 \\
\hline & MSPE decomposition & & & & \\
\hline & Mean bias, \% & & 43.4 & 45.2 & 3.1 \\
\hline & Regression error, \% & & 0.0 & 0.1 & 4.4 \\
\hline & Random error, $\%$ & & 56.6 & 54.7 & 92.5 \\
\hline
\end{tabular}

${ }^{1} \mathrm{MSPE}=$ mean square prediction error; RMSE $=$ root mean square error.

${ }^{2}$ AMTS = Agricultural Modeling and Training Systems LLC (Cortland, NY); CPM = Cornell-Penn-Miner Dairy version 3.0.10 [Cornell University (Ithaca, NY), University of Pennsylvania (Philadelphia), The William H. Miner Agricultural Research Institute (Chazy, NY), and the University of Maryland (College Park) cooperating]; OFF = calculated from Offner and Sauvant (2004).

those of other authors (Nocek and Tamminga, 1991; Firkins et al., 2001). A slight but significant positive association was observed in the present data set between the percent of RSDeg and the percent of TT [84.68+ $\left.(0.131 \times \mathrm{RSDeg}), \mathrm{R}^{2}=0.13\right]$, in agreement with Theurer et al. (1999), although the correlation was greater in their study. Regression of starch types with associated processing factors generally produced equations with high coefficients of determination. However, the numbers of samples were small and when evaluated, often produced RSDeg of greater than $100 \%$. Therefore, they were considered inaccurate and are not reported.

\section{Predictions by Existing Models}

Predictions of RSDeg, PRSDig, and TT derived from AMTS, CPM, and OFF were compared with observed values (Tables 4-7). For ease of description when discussing model accuracy, we have arbitrarily used a distinction in which mean prediction within $5 \%$ of the observed was considered very accurate, within $10 \%$ was accurate, within $15 \%$ was acceptable, and above $15 \%$ was not a useful prediction.

Across all diets on a percent basis, these 3 models predicted mean TT very accurately and had similar means and MSPE, although a difference in the source of error was found. The OFF model displayed a regression equation with an intercept closer to 0 and a slope closer to 1 than the other models, indicating a more robust model of TT. Although the MSPE was slightly larger, OFF also displayed less mean bias and regression bias with considerably more random error than AMTS or CPM. In terms of RSDeg, AMTS and CPM predictions were not useful, overpredicting by greater than $20 \%$, whereas OFF estimated very accurately within $5 \%$ of observed values. Most of the error in the AMTS and CPM predictions of RSDeg resulted from mean bias. For all models, developed regression equations for RSDeg had large intercepts and poor slope agreement as well as high RMSE as percentage of observed mean. This indicates that there may be room to improve prediction of RSDeg. Similarly, the predictions of PRSDig 
Table 5. Comparisons of existing models for starch digestion on a percentage basis in diets for adult dairy cows with corn grain $(\mathrm{n}=82)$ as the major starch source

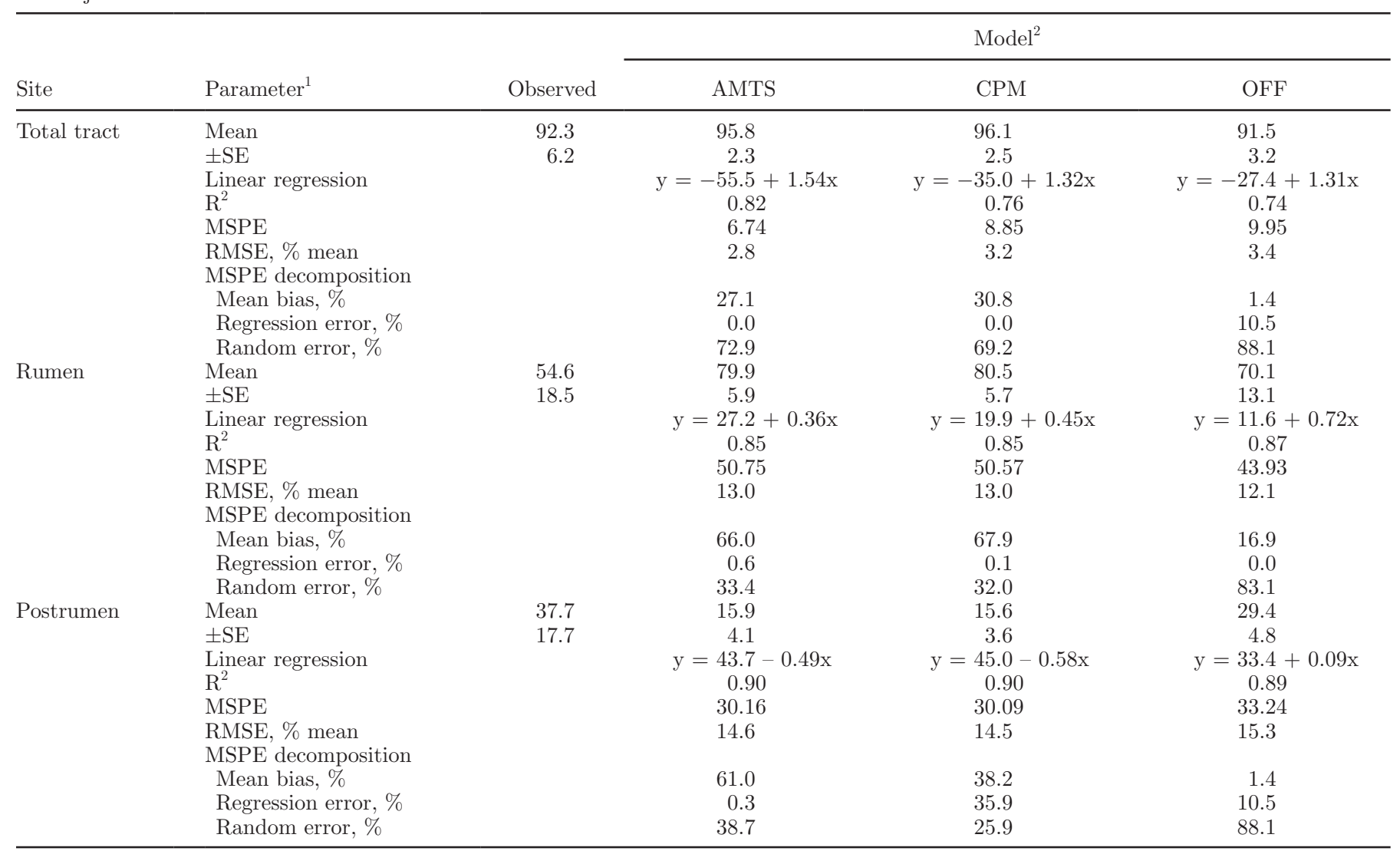

${ }^{1} \mathrm{MSPE}=$ mean square prediction error; RMSE $=$ root mean square error.

${ }^{2}$ AMTS = Agricultural Modeling and Training Systems LLC (Cortland, NY); CPM = Cornell-Penn-Miner Dairy version 3.0.10 [Cornell University (Ithaca, NY), University of Pennsylvania (Philadelphia), The William H. Miner Agricultural Research Institute (Chazy, NY), and the University of Maryland (College Park) cooperating]; OFF = calculated from Offner and Sauvant (2004).

by the AMTS and CPM models were not useful, underpredicting the observed mean by $15 \%$, due to the overprediction of RSDeg. The OFF predicted PRSDig very accurately. The MSPE decomposition for the OFF model displayed much greater random error and less mean bias, although regression equations, coefficients of determination, and MSPE were similar among all 3 models.

For corn-based diets, the mean TT was again very accurately predicted by the 3 models and displayed similar trends as noted for TT across all starch sources (Table 5). However, estimates of RSDeg by these models were not useful, with OFF overpredicting the observed mean RSDeg by $15 \%$ and AMTS and CPM overpredicting by greater than $25 \%$. The RMSE as percentage of mean and MSPE were similar among models predicting RSDeg in corn-based diets. For RSDeg of this diet type, the OFF model displayed less mean bias with an intercept and slope of the linear regression displaying more acceptable values than AMTS and CPM. Neither AMTS nor CPM made useful predictions of PRSDig, although OFF predicted accurately. For PRSDig, OFF displayed a larger MSPE, but it had a much larger random error. Some of the inaccuracy in prediction of RSDeg and PRSDig by OFF for corn-based diets may be due to differences in processing methods, which were not well reflected in the $\mathrm{kd}$ of the Offner et al. (2003) data set. This is also true of the AMTS and CPM models to a lesser extent because although processing of grains were added when present in the study, these effects were not commonly reported.

As was true for all starch sources and corn starch sources, the mean TT of small grains was very accurately predicted by all 3 models compared with mean observed values (Table 6). The OFF model displayed a more acceptable decomposition of MSPE for small grain starches. The RMSE as percentage of mean and MSPE were similar between model predictions. However, the linear regression displayed an intercept closer to 0 and a slope closer to unity for the AMTS model. The regression models for CPM and OFF are far from these values, but the coefficient of determination values are not greatly different. Unlike the RSDeg for all feeds and corn-based diets, the 3 models predicted RSDeg of 
Table 6. Comparisons of existing models for starch digestion on a percentage basis in diets for adult dairy cows with small grain $(\mathrm{n}=58)$ as the major starch source

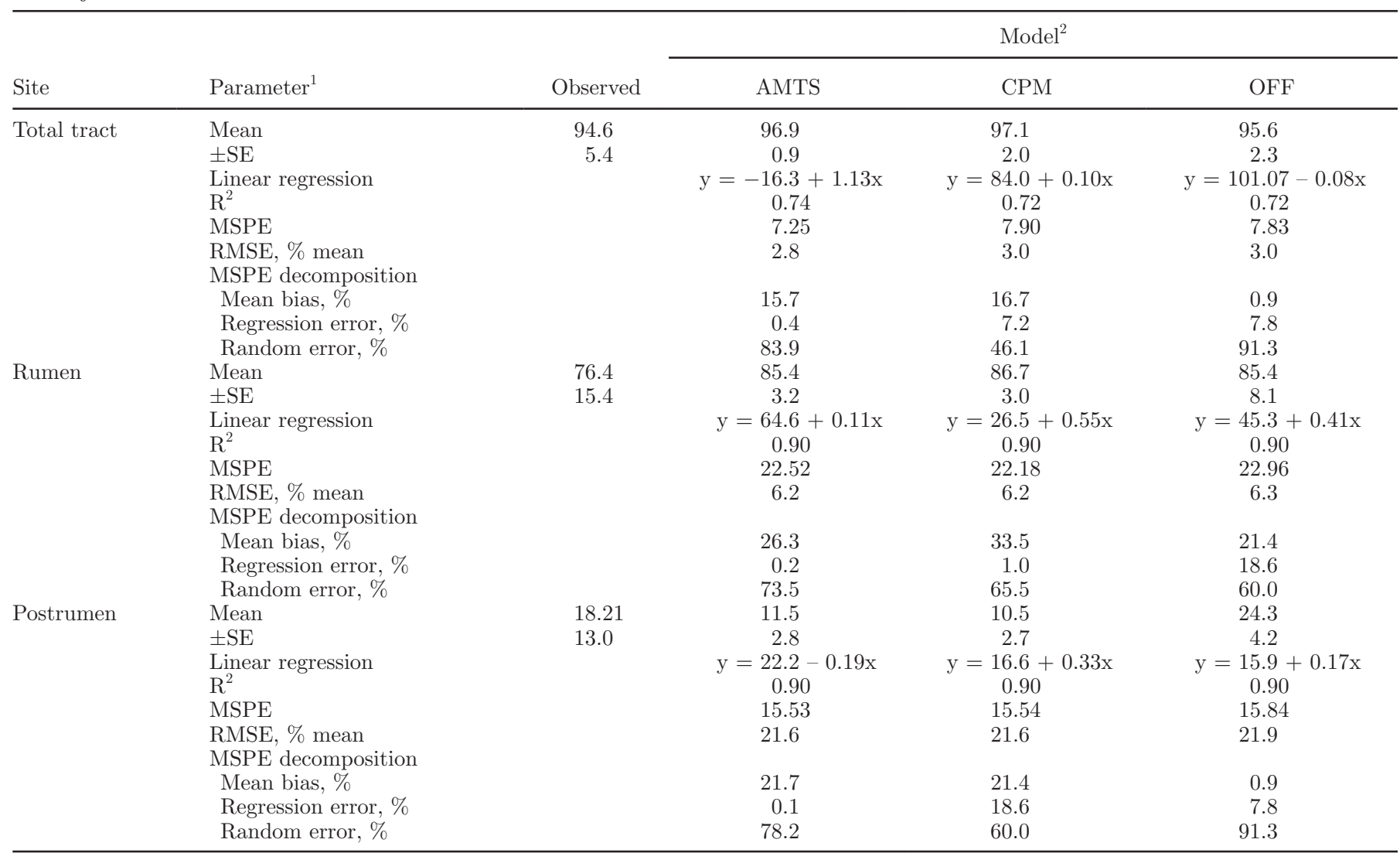

${ }^{1} \mathrm{MSPE}=$ mean square prediction error; RMSE $=$ root mean square error.

${ }^{2}$ AMTS = Agricultural Modeling and Training Systems LLC (Cortland, NY); CPM = Cornell-Penn-Miner Dairy version 3.0.10 [Cornell University (Ithaca, NY), University of Pennsylvania (Philadelphia), The William H. Miner Agricultural Research Institute (Chazy, NY), and the University of Maryland (College Park) cooperating]; OFF = calculated from Offner and Sauvant (2004).

small grains accurately compared with observed mean values and very close to each other, overpredicting RSDeg for small grains by approximately 10\%. Although the MSPE was very similar among the models, the OFF model exhibited a larger percent of regression error than the other models. All models displayed regression equations that had intercepts significantly larger than 0 (26.5 to 64.6), yet all displayed coefficients of determination of 0.90 . The overprediction of RSDeg resulted in underprediction of PRSDig for small grains by 6.7, 7.7, and $8.0 \%$ for AMTS, CPM, and OFF, respectively. Values for other types of model evaluations were similar, with the exception of the decomposition of MSPE, which displayed a larger mean bias for AMTS and CPM, a larger random error for OFF, and a larger regression error for the CPM model. For sorghum sources, TT was overpredicted by all 3 models, acceptably by AMTS and CPM, and accurately by OFF (Table 7). All linear regressions had exceptionally large negative intercepts $(-133.7,-134.9$, and -601.2$)$ and comparatively large slopes $(2.28,2.28$, and 7.57$)$ for AMTS, CPM, and OFF, respectively. All 3 models also displayed a large mean bias and relatively small random error in decomposition of TT MSPE for sorghum. The AMTS and CPM models considerably overpredicted RSDeg for sorghum sources. The OFF model predicted sorghum RSDeg accurately but displayed more regression error. Although TT and RSDeg were overpredicted for sorghum, the result was very accurate predictions of PRSDig for AMTS and CPM and an accurate prediction for OFF. Linear regression equations for PRSDig of sorghum display more desirable intercept and slope parameters, although the coefficients of determination of all equations were rather lower than the coefficients of determination of other sorghum fractions or for PRSDig of other starch sources. The starch data from sorghum may need to be discounted because of the few diets included in this analysis.

Standardization of model evaluation is always a difficult process (Tedeschi, 2006). In the present context, the RSDeg and PRSDig may be used to predict energy and energy substrates for ration balancing. This, in turn, 
Table 7. Comparisons of existing models for starch digestion on a percentage basis in diets for adult dairy cows with sorghum grain $(\mathrm{n}=8$ ) as the major starch source

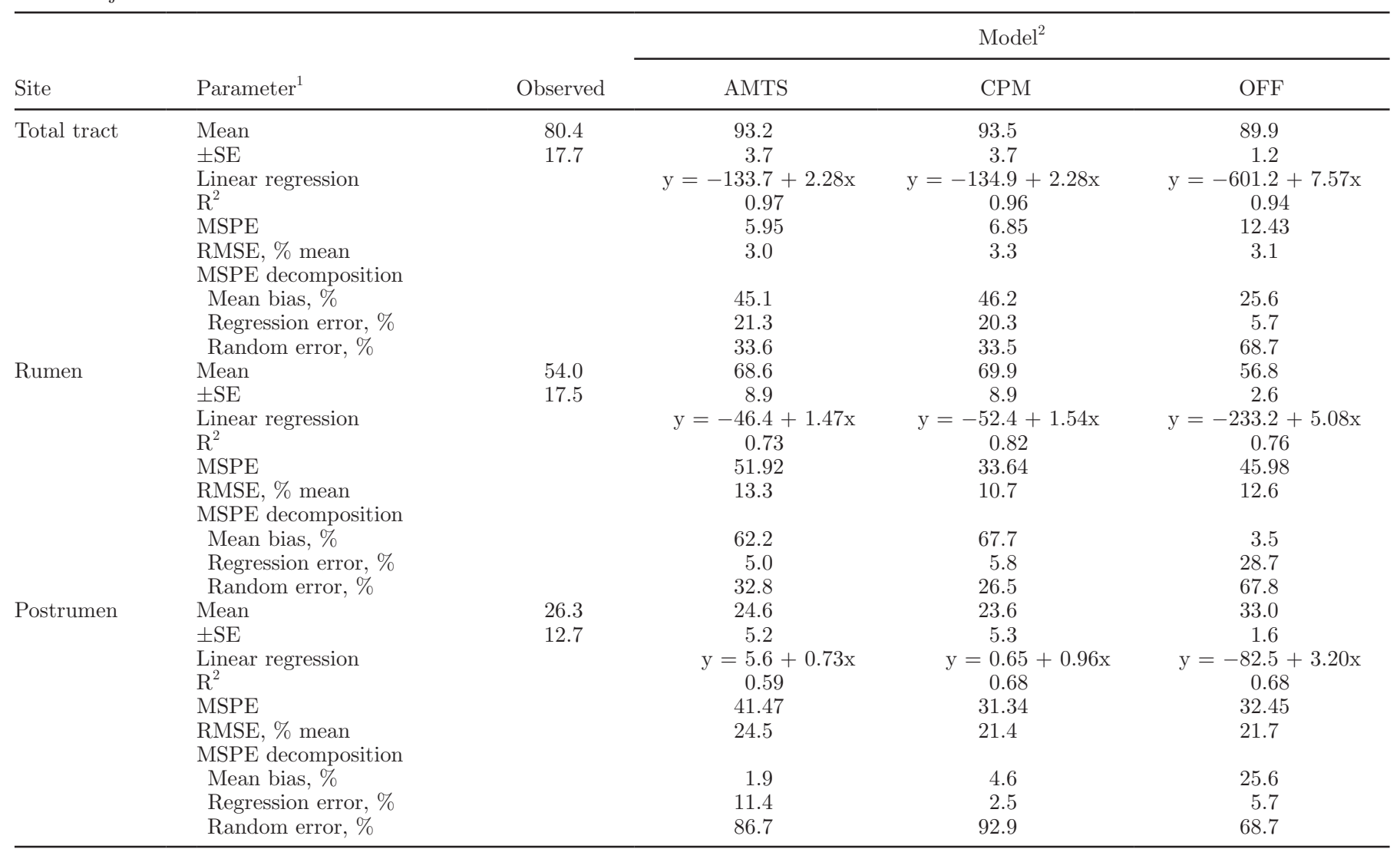

${ }^{1} \mathrm{MSPE}=$ mean square prediction error; RMSE $=$ root mean square error.

${ }^{2}$ AMTS = Agricultural Modeling and Training Systems LLC (Cortland, NY); CPM = Cornell-Penn-Miner Dairy version 3.0.10 [Cornell University (Ithaca, NY), University of Pennsylvania (Philadelphia), The William H. Miner Agricultural Research Institute (Chazy, NY), and the University of Maryland (College Park) cooperating]; OFF = calculated from Offner and Sauvant (2004).

implies that poorly estimated RSDeg and PRSDig, because of failure to predict the mean with a sufficiently low MSPE, may result in suboptimal ration balance. Poor accuracy in predicting the site of starch utilization would appear to have different metabolic consequences with respect to propionate and glucose production. Of these 3 models, OFF predicted the mean RSDeg with greater accuracy and greater precision, which suggests adjustment of this model has the greatest potential to more accurately predict RSDeg. It also appears that differences in RSDeg between AMTS and CPM were due to differences in predicted $\mathrm{kp}$. With the exception of sorghum grains, AMTS and CPM overpredicted RSDeg and underpredicted PRSDig. However, most of this error was related to a mean bias, which may be corrected by adding a constant term as did Offner and Sauvant (2004). It should not be surprising that AMTS and CPM displayed similar predictions and parameter values, as they are both derived from the Cornell Net Protein Carbohydrate System.

\section{SM Model}

Because there appeared to be room for improvement in predicting RSDeg, an attempt was made to develop models that would better predict this data set using the terms of the Orskov and McDonald (1979) equation. First, simple averages of RSDeg and TT were developed. This method has been shown to be accurate for predicting AA flows from RUP (Patton and Stevenson, 2000). Grain processing was included in this determination to the extent possible, and the means derived for individual feedstuffs are presented in Table 8. It is interesting to note that this method produced a mean observed RSDeg for all corn sources with the exception of high-moisture shelled corn that was reasonably consistent. Likewise, mean estimates of barley grain RSDeg were similar to each other, whether ground or steam rolled. The means for RSDeg and TT were close to those first proposed by Firkins et al. (2001) as well as Theurer et al. (1999) and Owens (2005), except for 
RSDeg of high-moisture corn, which was estimated to be less in the current study than the others. The idea of using a mean value was appealing because of its simplicity and, as suggested by Owens (2005), factors other than inherent degradability and processing factors probably have less than a $2 \%$ effect on overall degradability.

However, problems arise using this method for determining in vivo digestibility of individual feeds, especially feeds that have low starch content or that are included at low levels. Often, the minimum possible degradation for these feeds was $0.1 \%$, and the maximum was $99.9 \%$ by definition. This resulted in a mean calculation of $50 \%$ RSDeg, which may not be very meaningful. Also, because the data set that was used to develop the SM values is almost exactly the same as the data set used to evaluate it, care must be exercised when discussing the relative merits of these values in relation to the other models evaluated (Gill, 1978). Across all diets, use of the simple means for starch degradation resulted in a model that predicted the mean RSDeg percent with improved accuracy and which had the smallest

Table 8. Simple means of percent starch ruminally degraded (RSDeg) and percent starch digested in total tract (TT) for various feeds fed to adult dairy cattle

\begin{tabular}{|c|c|c|c|c|c|}
\hline Feed & Comparisons & RSDeg & $\pm \mathrm{SE}$ & $\mathrm{TT}$ & $\pm \mathrm{SE}$ \\
\hline Alfalfa cubes & 4 & 50.0 & - & 55.0 & - \\
\hline Alfalfa hay & 38 & 50.0 & 0.2 & 62.3 & 16.5 \\
\hline Alfalfa silage & 53 & 50.0 & 4.0 & 52.4 & 9.2 \\
\hline Barley grain, dry rolled & 8 & 69.0 & 6.3 & 98.9 & 2.9 \\
\hline Barley grain, ground & 14 & 68.7 & 4.2 & 96.7 & 1.6 \\
\hline Barley grain, steam rolled & 25 & 69.2 & 7.7 & 95.2 & 2.5 \\
\hline Barley silage & 15 & 50.1 & 0.3 & 81.1 & 16.9 \\
\hline Beet pulp & 21 & 47.8 & 7.5 & 83.4 & 15.3 \\
\hline Brewers grains, dried & 1 & 50.5 & - & 74.5 & 34.6 \\
\hline Canola meal & 14 & 51.8 & 6.3 & 79.7 & 12.2 \\
\hline Corn distillers grain, dried & 16 & 48.1 & 4.0 & 50.0 & - \\
\hline Corn gluten feed & 4 & 50.0 & - & 87.5 & 8.7 \\
\hline Corn gluten meal & 18 & 50.0 & - & 76.3 & 11.0 \\
\hline Corn grain, cracked & 11 & 54.6 & 6.0 & 89.0 & 6.1 \\
\hline Corn grain, ground ${ }^{1}$ & 57 & 59.4 & 10.3 & 93.2 & 3.2 \\
\hline Corn grain, high moisture & 8 & 68.8 & 11.3 & 94.3 & 6.9 \\
\hline Corn grain, steam flaked ${ }^{2}$ & 18 & 60.5 & 12.5 & 95.7 & 4.3 \\
\hline Corn silage & 60 & 50.5 & 13.7 & 87.7 & 2.7 \\
\hline Corn starch & 4 & 82.7 & 21.5 & 98.5 & 1.7 \\
\hline Cottonseed meal & 5 & 51.0 & 1.9 & 76.3 & 19.0 \\
\hline Cottonseed, whole w/lint & 30 & 49.8 & 0.9 & 59.9 & 13.9 \\
\hline Grass hay & 5 & 50.0 & - & 67.7 & 20.5 \\
\hline Grass silage & 16 & 49.1 & 2.7 & 52.9 & 11.5 \\
\hline Hominy feed & 1 & 45.3 & - & 98.5 & - \\
\hline Linseed, whole & 2 & 50.0 & - & 95.0 & - \\
\hline Linseed meal & 4 & 50.0 & - & 94.0 & - \\
\hline Mixed alfalfa-grass silage & 4 & 49.1 & - & 52.9 & 8.8 \\
\hline Oats, ground & 6 & 67.0 & 7.1 & 94.2 & 0.3 \\
\hline Palm kernel meal & 4 & 50.0 & - & 77.0 & 0.5 \\
\hline Peas, ground & 2 & 50.0 & - & 87.5 & 3.5 \\
\hline Ryegrass pasture & 8 & 51.3 & 2.2 & 64.5 & 14.3 \\
\hline Sorghum grain, dry rolled & 6 & 47.0 & 6.8 & 82.7 & 5.5 \\
\hline Sorghum grain, steam flaked & 4 & 71.9 & 10.3 & 97.5 & 4.8 \\
\hline Soybean hulls & 11 & 53.9 & 9.0 & 76.8 & 16.6 \\
\hline Soybean meal ${ }^{3}$ & 99 & 50.4 & 6.6 & 84.8 & 17.8 \\
\hline Soybean meal, expeller & 6 & 50.0 & - & 73.0 & 20.1 \\
\hline Soybeans, whole, roasted & 1 & 50.0 & - & 85.0 & - \\
\hline Soybeans, whole, raw & 2 & 50.0 & - & 85.0 & 10.0 \\
\hline Sunflower meal & 4 & 50.0 & - & 67.9 & 19.3 \\
\hline Wheat bran & 4 & 50.0 & - & 90.0 & 10.0 \\
\hline Wheat flour & 4 & 68.7 & 1.0 & 96.4 & 0.5 \\
\hline Wheat germ meal & 2 & 50.0 & - & 82.1 & 18.3 \\
\hline Wheat grain, ground & 20 & 70.0 & 2.4 & 96.3 & 1.3 \\
\hline Wheat grain, steam rolled & 3 & 74.4 & 2.4 & 96.9 & 0.1 \\
\hline Wheat straw & 2 & 35.5 & 0.7 & 67.5 & 45.9 \\
\hline
\end{tabular}

${ }^{1}$ Includes all reported grinds.

${ }^{2}$ Includes corn reported as steam rolled.

${ }^{3}$ Includes both 44 and $48 \%$ soybean meals. 
Table 9. Comparisons of simple mean and developed rkd model for sites of starch digestion on a percentage basis for diets of adult dairy cows

\begin{tabular}{|c|c|c|c|c|}
\hline \multirow[b]{2}{*}{ Starch type } & \multirow[b]{2}{*}{ Site } & \multirow[b]{2}{*}{ Parameter $^{1}$} & \multicolumn{2}{|c|}{ Model $^{2}$} \\
\hline & & & $\mathrm{SM}$ & rkd \\
\hline \multirow[t]{3}{*}{ All } & Total tract & $\begin{array}{l}\text { Mean } \\
\pm \mathrm{SE} \\
\text { Linear regression } \\
\mathrm{R}^{2} \\
\text { MSPE } \\
\text { RMSE, \% mean } \\
\text { MSPE decomposition } \\
\quad \text { Mean bias, \% } \\
\text { Regression error, \% } \\
\text { Random error, \% }\end{array}$ & $\begin{array}{c}91.8 \\
3.5 \\
\mathrm{y}=10.2+0.90 \mathrm{x} \\
0.78 \\
11.54 \\
3.7 \\
11.54 \\
2.10 \\
0.80 \\
97.10\end{array}$ & $\begin{array}{c}91.8 \\
3.5 \\
\mathrm{y}=10.2+0.90 \mathrm{x} \\
0.78 \\
11.54 \\
3.7 \\
11.54 \\
2.10 \\
0.80 \\
97.10\end{array}$ \\
\hline & Rumen & $\begin{array}{l}\text { Mean } \\
\pm \mathrm{SE} \\
\text { Linear regression } \\
\mathrm{R}^{2} \\
\text { MSPE } \\
\text { RMSE, \% mean } \\
\text { MSPE decomposition } \\
\quad \text { Mean bias, \% } \\
\text { Regression error, \% } \\
\text { Random error, \% }\end{array}$ & $\begin{array}{c}60.2 \\
6.6 \\
\mathrm{y}=-29.1+1.5 \mathrm{x} \\
0.92 \\
35.32 \\
9.6 \\
\\
0.7 \\
0.3 \\
99.0\end{array}$ & $\begin{array}{c}61.4 \\
6.5 \\
\mathrm{y}=-45.2+1.73 \mathrm{x} \\
0.90 \\
42.96 \\
10.6 \\
\\
0.1 \\
11.2 \\
88.7\end{array}$ \\
\hline & Postrumen & $\begin{array}{l}\text { Mean } \\
\pm \mathrm{SE} \\
\text { Linear regression } \\
\mathrm{R}^{2} \\
\text { MSPE } \\
\text { RMSE, \% mean } \\
\text { MSPE decomposition } \\
\text { Mean bias, \% } \\
\text { Regression error, \% } \\
\text { Random error, \% }\end{array}$ & $\begin{array}{c}31.6 \\
4.5 \\
\mathrm{y}=-16.8+1.52 \mathrm{x} \\
0.86 \\
49.94 \\
22.9 \\
\\
0.1 \\
0.2 \\
99.7\end{array}$ & $\begin{array}{c}30.3 \\
5.4 \\
\mathrm{y}=-5.5+1.21 \mathrm{x} \\
0.83 \\
62.00 \\
25.6 \\
\\
0.1 \\
3.3 \\
96.6\end{array}$ \\
\hline \multirow{2}{*}{ Corn } & Rumen & $\begin{array}{l}\text { Mean } \\
\pm \mathrm{SE} \\
\text { Linear regression } \\
\mathrm{R}^{2} \\
\text { MSPE } \\
\text { RMSE, \% mean } \\
\text { MSPE decomposition } \\
\quad \text { Mean bias, \% } \\
\text { Regression error, \% } \\
\text { Random error, \% }\end{array}$ & $\begin{array}{c}58.9 \\
6.5 \\
\mathrm{y}=-8.6+1.08 \mathrm{x} \\
0.91 \\
28.32 \\
9.8 \\
\\
5.4 \\
1.1 \\
93.5\end{array}$ & $\begin{array}{c}58.8 \\
4.9 \\
\mathrm{y}=-47.1+1.74 \mathrm{x} \\
0.88 \\
38.48 \\
0.1 \\
\\
5.4 \\
0.4 \\
94.2\end{array}$ \\
\hline & Postrumen & $\begin{array}{l}\text { Mean } \\
\pm \mathrm{SE} \\
\text { Linear regression } \\
\mathrm{R}^{2} \\
\text { MSPE } \\
\text { RMSE, \% mean } \\
\text { MSPE decomposition } \\
\text { Mean bias, \% }\end{array}$ & $\begin{array}{c}33.1 \\
4.5 \\
\mathrm{y}= \\
11.8+0.74 \mathrm{x} \\
0.90 \\
28.84 \\
14.2 \\
6.3\end{array}$ & $\begin{array}{c}33.2 \\
4.3 \\
\mathrm{y}= \\
27.2+0.26 \mathrm{x} \\
0.88 \\
33.30 \\
15.3 \\
6.4\end{array}$ \\
\hline
\end{tabular}


Table 9 (Continued). Comparisons of simple mean and developed rkd model for sites of starch digestion on a percentage basis for diets of adult dairy cows

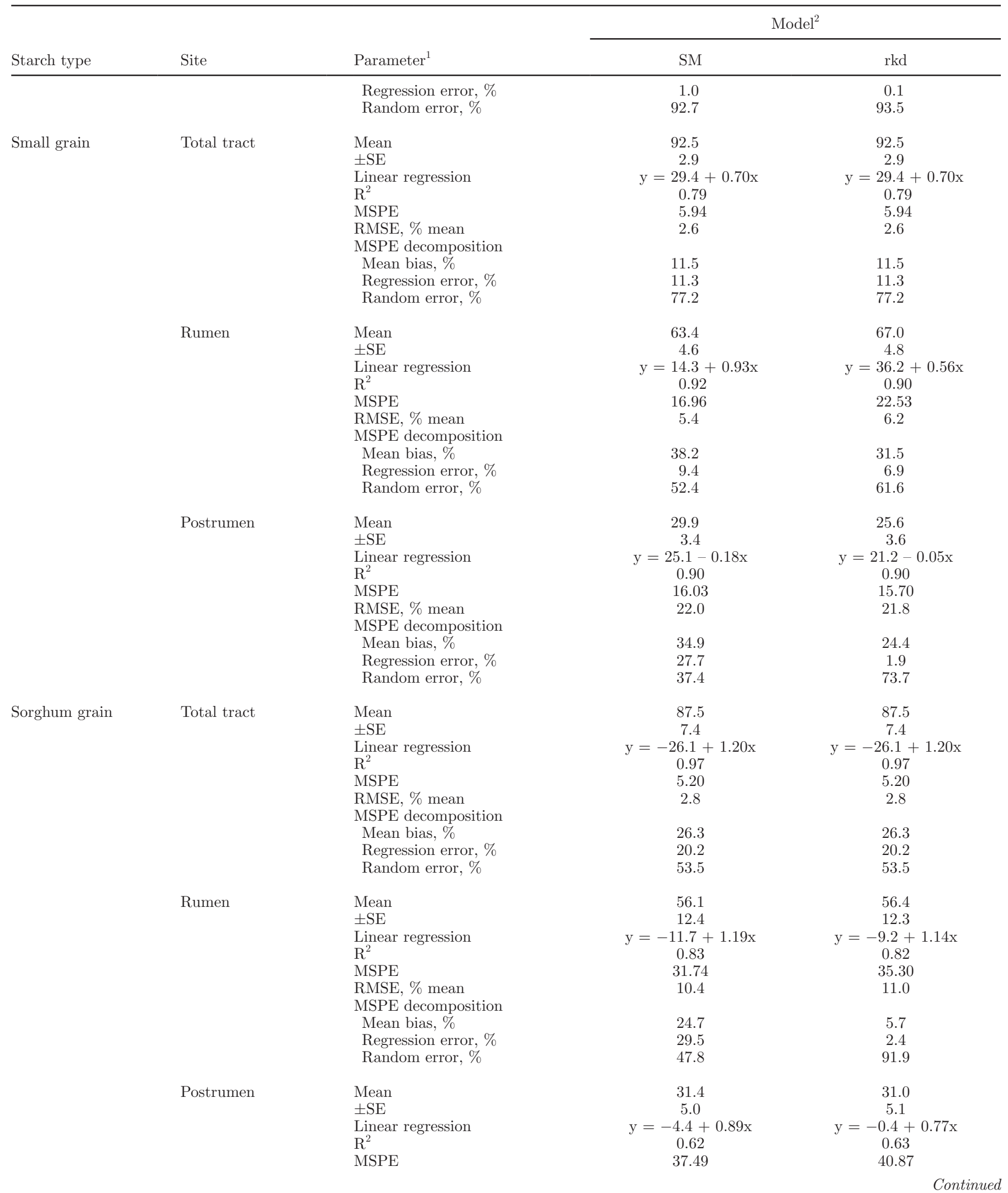


Table 9 (Continued). Comparisons of simple mean and developed rkd model for sites of starch digestion on a percentage basis for diets of adult dairy cows

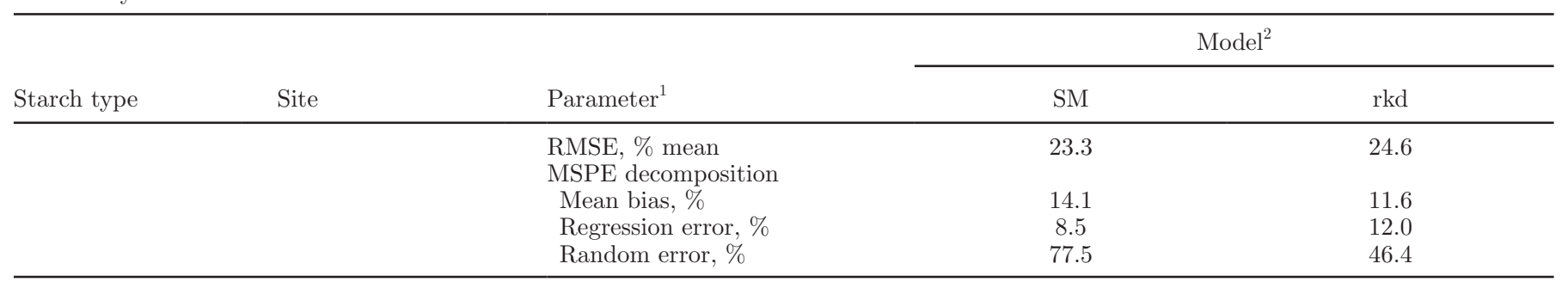

${ }^{1} \mathrm{MSPE}=$ mean square prediction error; RMSE $=$ root mean square error.

${ }^{2} \mathrm{SM}=$ simple mean model in which the calculated means of ruminal starch degradability (RSDeg) and postruminal starch digestion (PRSDig) were applied to each ration; rkd $=$ revised rate of digestion model.

MSPE and highest percent random error (Table 9). Across all diets and with starch sources other than small grains, the SM model provided more accurate estimates of RSDeg when compared with observed means with smaller MSPE and higher random error in this decomposition. Unfortunately, the SM model greatly underpredicted RSDeg and PRSDig for small grains when compared with other models. Inspection of individual diets indicated that the problem was with the prediction of RSDeg of ground barley diets. The reason SM should predict so poorly for ground barley diets is not presently known, but it may be related to adjustment of study effects, which may have led to a bias. The accuracy of the SM model for corn starch sources seems to indicate that 2 starch fractions may exist in corn. One fraction is a readily fermentable fraction, and the other is a fraction resistant to rumen microbial action but readily digestible in the small intestine. Less evidence exists for similar fractions for small grains and sorghum, although greater sample numbers may reveal a similar situation for these starches.

\section{Revised kd Model}

Logically, the failure of OFF to sufficiently predict RSDeg must be from 1 of 3 sources: (1) the kd must be incorrect, (2) the kp must be badly estimated, or (3) some other factors must be operating. To study which of these factors was most likely the cause of this inaccuracy, the $\mathrm{kp}$ for each feed in each ration was calculated by the 4 methods cited: Seo et al. (2006) as used in AMTS, Chalupa et al. (1991) as used in CPM, and Offner and Sauvant (2004); the $\mathrm{kp}$ as calculated by NRC (2001) was included for comparison. Across all feeds and all diets, the $\mathrm{kp}$ for Seo et al. (2006), Chalupa et al. (1991), Offner and Sauvant (2004), and NRC (2001) for this data set was found to be 5.86, 5.60, 5.78, and $5.91 \%$ per hour, respectively. Because of these relatively small differences, it appeared that the estimation of $\mathrm{kp}$ was essentially correct in $\mathrm{OFF}$ and that it would take substantially large differences in $\mathrm{kp}$ to correct the deficiencies of prediction of RSDeg. Further, given the scope of the data summarized, it appeared that $k d$ for the in situ data of Offner et al. (2003) reflected closely the in situ starch degradability of various feeds when determined in cattle. Therefore, other factors must be responsible for this difference in RSDeg. One such factor that could influence the RSDeg difference might be the differences between commercially processed grain and that ground to the 2 to $5 \mathrm{~mm}$ recommended for the in situ starch determination (Nocek, 1988). The structure, moisture, and vitreousness of the starch source can also influence degradation kinetics (Mills et al., 1999), and these factors must be considered a possible source of deviation. Moreover, the protein matrix surrounding the starch granules (McAllister et al., 1993) and protozoal populations (Mendoza et al., 1993) have been shown to negatively affect RSDeg. When it was reported, grind size was sometimes reported as grams per liter or as mean particle size in millimeters. Because there does not appear to be a direct correlation between them, it is impossible to separate the effects of processing from effects of starch structure using this data set. For example, when determining simple means, we found that ground corn $(\mathrm{n}=57)$ had a calculated mean degradability of $59.4 \%$, but the standard error was $\pm 10.3 \%$. Steam-flaked corn had a calculated mean degradability of $60.5 \pm 12.5 \%$. This large amount of variation in these feeds suggests more difference than might be expected for consistent grain processing. Better reporting of grain processing, vitreousness, and particle size may lead to better estimates of in vivo RSDeg for different processing methods.

A revised kd to be used in the Ørskov and McDonald (1979) calculation was proposed to better blend the effects of processing and starch type in hopes of predicting RSDeg with greater accuracy. These calculations were performed assuming that the kp of Offner and Sauvant (2004) was approximately correct. This calculation was used because it is both intermediate between the 
Table 10. Revised rates of digestion (kd, \% per h) estimated for starch contained in various feeds fed to adult dairy cattle

\begin{tabular}{|c|c|c|c|}
\hline Feed & Determinations & $\mathrm{kd}$ & $\pm \mathrm{SE}$ \\
\hline Alfalfa cubes & 4 & 4.4 & - \\
\hline Alfalfa hay & 38 & 4.4 & 0.3 \\
\hline Alfalfa meal & 6 & 4.6 & 0.2 \\
\hline Alfalfa silage & 53 & 4.6 & 2.2 \\
\hline Barley grain, dry rolled & 8 & 15.3 & 9.1 \\
\hline Barley grain, ground & 14 & 15.8 & 2.2 \\
\hline Barley grain, steam rolled & 25 & 15.3 & 0.9 \\
\hline Barley silage & 15 & 4.5 & 0.2 \\
\hline Beet pulp & 21 & 5.8 & 0.8 \\
\hline Brewers grains, dried & 6 & 6.2 & 0.1 \\
\hline Canola meal & 14 & 6.5 & 0.9 \\
\hline Corn distillers grain, dried & 16 & 6.3 & 0.4 \\
\hline Corn gluten feed & 4 & 7.0 & 1.6 \\
\hline Corn gluten meal & 19 & 6.5 & 0.3 \\
\hline Corn grain, cracked & 9 & 8.4 & 0.6 \\
\hline Corn grain, ground ${ }^{1}$ & 62 & 9.7 & 0.9 \\
\hline Corn grain, high moisture & 8 & 15.5 & 1.4 \\
\hline Corn grain, steam flaked ${ }^{2}$ & 18 & 9.7 & 0.9 \\
\hline Corn silage & 60 & 4.6 & 0.3 \\
\hline Corn starch & 4 & 30.3 & 2.4 \\
\hline Cottonseed meal & 6 & 6.9 & 0.8 \\
\hline Cottonseed, whole with lint & 30 & 4.7 & 0.4 \\
\hline Grass hay & 5 & 4.3 & 0.1 \\
\hline Grass silage & 20 & 3.9 & 0.4 \\
\hline Hominy feed & 1 & 4.6 & - \\
\hline Linseed, whole & 2 & 6.0 & 0.1 \\
\hline Linseed meal & 4 & 5.6 & 1.6 \\
\hline Mixed alfalfa-grass silage & 4 & 4.5 & 0.2 \\
\hline Oats, ground & 6 & 11.5 & 2.8 \\
\hline Palm kernel meal & 4 & 5.6 & 0.2 \\
\hline Peas, ground & 2 & 5.6 & 0.3 \\
\hline Rapeseed meal & 6 & 5.7 & 1.4 \\
\hline Ryegrass pasture & 8 & 4.5 & 1.0 \\
\hline Sorghum grain, dry rolled & 6 & 5.7 & 0.4 \\
\hline Sorghum grain, steam flaked & 4 & 16.5 & 1.1 \\
\hline Soybean hulls & 14 & 7.8 & 0.6 \\
\hline Soybean meal ${ }^{3}$ & 109 & 6.5 & 0.7 \\
\hline Soybean meal, expeller & 6 & 7.3 & 0.5 \\
\hline Soybeans, whole, roasted & 1 & 6.2 & - \\
\hline Soybeans, whole, raw & 2 & 6.9 & 0.1 \\
\hline Sunflower meal & 4 & 5.8 & 0.1 \\
\hline Wheat bran & 4 & 6.1 & 0.1 \\
\hline Wheat flour & 4 & 14.7 & 0.2 \\
\hline Wheat germ meal & 2 & 6.8 & 0.1 \\
\hline Wheat grain, ground & 18 & 14.6 & 1.3 \\
\hline Wheat grain, steam rolled & 2 & 11.9 & 1.8 \\
\hline Wheat straw & 2 & 2.4 & - \\
\hline
\end{tabular}

${ }^{1}$ Includes all reported grinds.

${ }^{2}$ Includes corn reported as steam rolled.

${ }^{3}$ Includes both 44 and $48 \%$ soybean meals.

other kp estimates, and it is computationally simple. The revised kd values for individual ingredients are presented in Table 10. This model was evaluated as were the others, and analyses are presented in Table 9 also. The mean RSDeg and PRSDig estimations of rkd were similar to those of the SM method with larger MSPE and slope coefficients farther from 1. This similarity was primarily because the amounts of degraded and digested starch were taken from the MS model to back calculate the revised $\mathrm{kd}$. Thus, the rkd model failed to evaluate RSDeg and PRSDig of small grains well and overpredicted the TT of sorghum as well as overpredicted the amount of sorghum RSDeg. The rkd method should be evaluated as a method to enable the Ørskov and McDonald (1979) equation to predict the mean RSDeg, although refinement is required for prediction of RSDeg of small grain starches.

\section{Discarded Models}

Models of RSDeg based on regression of TT digestibility, both across and within feed type as well as from 
regression models within feed type, produced prediction of low accuracy and precision, so they were discarded. Use of rkd predicted as a percentage of starch present for each ingredient all produced a model with low accuracy. In spite of the high correlation of RSDeg within processing type, when these same groups of diets, which were used to develop these equations, were subjected to the AMTS, CPM, OFF, SM, and rkd models, with the exception of ground corn and ground barley, predictions of mean RSDeg values were highly accurate, but the associated regression equations had extremely high intercepts with negative slopes. The negative slopes across all models indicated that the amount of data associated with processing effects was not sufficient for model evaluation.

\section{CONCLUSIONS}

Across all feeds, the OFF, SM, and rkd models predicted RSDeg and PRSDig more accurately than the AMTS and CPM models. The use of revised kd values in the equation of Ørskov and McDonald (1979) has the potential to improve the in vivo prediction of RSDeg. Further, it appears that more careful reporting of starch structure, particle size, and processing method when measuring in vivo RSDeg and TT will provide opportunities to not only better predict the amount and types of energy fuels, but may also result in more accurate prediction of rumen microbial protein.

\section{REFERENCES}

Aman, P., and K. Hesselman. 1984. Analysis of starch and other main components of cereal grain. Swed. J. Agric. Res. 14:135-139.

Bibby, J., and H. Toutenburg. 1977. Chapter 1: Basic ideas. Pages 16-19 in Prediction and Improved Estimation in Linear Models. John Wiley \& Sons, London, UK.

Chalupa, W., C. J. Sniffen, D. G. Fox, and P. J. Van Soest. 1991. Model generated protein degradation nutritional information. Pages 44-51 in Proc. Cornell Nutrition Conference, Cornell University, Ithaca, NY.

Doreau, M., A. Delacroix, J. P. Jouany, C. Durier, and B. Remond. 1990. The influence of physiological state and dietary nitrogen supply on digestion in the dairy cow. J. Anim. Sci. 68:3853-3860.

Faisant, N., V. Planchot, F. Kozlowski, M. P. Pacouret, P. Colonna, and M. Champ. 1995. Resistant starch determination adapted to products containing high level of resistant starch. Sci. Aliments 15:83-89.

Firkins, J. L., M. L. Eastridge, N. R. St-Pierre, and S. M. Noftsger. 2001. Effects of grain variability and processing on starch utilization by lactating dairy cattle. J. Anim. Sci. 79(E. Suppl.):E219E238.

Gill, J. L. 1978. Pages 111-112 in Design and Analysis of Experiments in the Animal and Medical Sciences. Vol. 1. The Iowa State University Press, Ames.

Hall, M. B. 2004. Short communication: Effect of carbohydrate fermentation rate on estimates of mass fermented and milk response. J. Dairy Sci. 87:1455-1456.

Herrera-Saldana, R. E., J. T. Huber, and M. H. Poore. 1990. Dry matter, crude protein and starch degradability of five cereal grains. J. Dairy Sci. 73:2386-2393.
Karkalas, J. 1985. An improved enzymatic method for the determination of native and modified starch. J. Sci. Food Agric. 36:10191027.

McAllister, T. A., R. C. Phillippe, L. M. Rode, and K. J. Cheng. 1993. Effect of the protein matrix on the digestion of cereal grains by ruminal microorganisms. J. Anim. Sci. 71:205-212.

Mendoza, G. D., R. A. Britton, and R. A. Stock. 1993. Influence of ruminal protozoa on site and extent of starch digestion and ruminal fermentation. J. Anim. Sci. 71:1572-1578.

Mills, J. A. N., J. France, and J. Dijkstra. 1999. A review of starch digestion in the lactating dairy cow and proposals for a mechanistic model: 1. Dietary starch characterization and ruminal starch digestion. J. Anim. Feed Sci. 8:291-340.

Nocek, J. E. 1988. In situ and other methods to estimate ruminal protein and energy digestibility: A review. J. Dairy Sci. 71:20512069.

Nocek, J. E., and S. Tamminga. 1991. Site of digestion of starch in the gastrointestinal tract of dairy cows and its effect on milk yield and composition. J. Dairy Sci. 74:3598-3629.

NRC. 2001. Nutrient Requirements of Dairy Cattle, 7th rev. ed. Natl. Acad. Sci., Washington, DC.

Offner, A., A. Bach, and D. Sauvant. 2003. Quantitative review of in situ starch degradation in the rumen. Anim. Feed Sci. Technol. 106:81-93.

Offner, A., and D. Sauvant. 2004. Prediction of in vivo starch digestion in cattle from in situ data. Anim. Feed Sci. Technol. 111:41-56.

Ørskov, E. R., and I. McDonald. 1979. The estimation of protein degradability in the rumen from incubation measurements weighted according to rate of passage. J. Agric. Sci. (Camb.) 92:499-503.

Owens, F. 2005. Corn grain processing and digestion. Pioneer Hi-Bred International Inc., Johnston, IA. Accessed Dec. 14, 2011. http:// www.ddgs.umn.edu/articles-proc-storage-quality/2005-Owens $\% 20$ (MNC)\%20Corn\%20grain\%20proc.pdf.

Pacheco, D., C. G. Schwab, R. Berthiaume, G. Raggio, and H. Lapierre. 2006. Comparison of net portal absorption with predicted flow of digestible amino acids: Scope for improving current models? J. Dairy Sci. 89:4747-4757.

Patton, R. A., and M. J. Stevenson. 2000. Estimating the undegradability of intake protein using duodenal flows: A literature study. J. Dairy Sci. 83(Suppl. 1):66. (Abstr.)

Reynolds, C. K. 2006. Production and metabolic effects of site of starch digestion in dairy cattle. Anim. Feed Sci. Technol. 130:78-94.

Seo, S., L. O. Tedeschi, C. Lanza, C. G. Schwab, and D. G. Fox. 2006. Development and evaluation of empirical equations to predict feed passage rate in cattle. Anim. Feed Sci. Technol. 128:67-83.

Sniffen, C. J., J. D. O'Connor, P. J. Van Soest, D. G. Fox, and J. B. Russell. 1992. A net carbohydrate and protein system for evaluating cattle diets: II. Carbohydrate and protein availability. J. Anim. Sci. 70:3562-3577.

St-Pierre, N. R. 2001. Invited review: Integrating quantitative finds from multiple studies using mixed model methodology. J. Dairy Sci. 84:741-755.

Stern, M. D., and W. H. Hoover. 1979. Methods for determining and factors affecting rumen microbial protein synthesis: A review. J. Anim. Sci. 49:1590-1603.

Tedeschi, L. O. 2006. Assessment of the adequacy of mathematical models. Agric. Syst. 89:225-247.

Theurer, C. B., J. T. Huber, A. Delgado-Elorduy, and R. Wanderley. 1999. Invited review: Summary of steam-flaking corn or sorghum grain for lactating dairy cows. J. Dairy Sci. 82:1950-1959.

Tylutki, T. P., D. G. Fox, V. M. Durbal, L. O. Tedeschi, J. B. Russell, M. E. Van Amburgh, T. R. Overton, L. E. Chase, and A. N. Pell. 2008. Cornell net carbohydrate and protein system: A model for precision feeding of dairy cattle. Anim. Feed Sci. Technol. $143: 174-202$.

Volden, H. 1999. Effects of level of feeding and ruminally undegraded protein on ruminal bacterial protein synthesis, escape of dietary protein, intestinal amino acid profile, and performance of dairy cows. J. Anim. Sci. 77:1905-1918. 


\section{APPENDIX 1. LIST OF STUDIES USED TO DETERMINE RUMINAL STARCH DEGRADATION AND TOTAL-TRACT STARCH DIGESTION}

Avila, C. D., E. J. DePeters, H. Perez-Monti, S. J. Taylor, and R. A. Zinn. 2000. Influences of saturation ratio of supplemental dietary fat on digestion and milk yield in dairy cows. J. Dairy Sci. $83: 1505-1519$

Beauchemin, K. A., W. Z. Yang, and L. M. Rode. 1999. Effects of grain source and enzyme additive on site and extent of nutrient digestion in dairy cows. J. Dairy Sci. 82:378-390.

Bernard, J. K., P. T. Chandler, J. W. West, A. H. Parks, H. A. Amos, M. A. Froetschel, and D. S. Trammell. 2004. Effect of supplemental L-lysine-HCL and corn source on rumen fermentation and amino acid flow to the small intestine. J. Dairy Sci. 87:399-405.

Cameron, M. R., T. H. Klusmeyer, G. L. Lynch, J. H. Clark, and D. R. Nelson. 1991. Effects of urea and starch on rumen fermentation, nutrient passage to the duodenum, and performance of cows. J. Dairy Sci. 74:1321-1336.

Christensen, R. A., M. R. Cameron, T. H. Klusmeyer, J. P. Elliot, J. H. Clark, D. R. Nelson, and Y. Yu. 1993. Influence of amount and degradability of dietary protein on nitrogen utilization by dairy cows. J. Dairy Sci. 76:3497-3513.

Christensen, R. A., T. R. Overton, J. H. Clark, J. K. Drackley, D. R. Nelson, and S. A. Blum. 1996. Effects of dietary fat with or without nicotinic acid on nutrient flow to the duodenum of dairy cows. J. Dairy Sci. 79:1410-1424.

Crocker, L. M., E. J. DePeters, J. G. Fadel, H. Perez-Monti, S. J. Taylor, J. A. Wyckoff, and R. A. Zinn. 1998. Influence of processed corn grain in diets of dairy cows on digestion of nutrients and milk composition. J. Dairy Sci. 81:2394-2407.

Doreau, M., A. Delacroix, J. P. Jouany, C. Durier, and B. Remond. 1990. The influence of physiological state and dietary nitrogen supply on digestion in the dairy cow. J. Anim. Sci. 68:3853-3860.

Espindola, M. S., E. J. DePeters, J. G. Fadel, R. A. Zinn, and H. Perez-Monti. 1997. Effects on nutrient digestion of wheat processing and method of tallow addition to the diets of lactating dairy cows. J. Dairy Sci. 80:1160-1171.

Foley, A. E., A. N. Hristov, A. Melgar, J. K. Ropp, R. P. Etter, S. Zaman, C. W. Hunt, K. Huber, and W. J. Price. 2006. Effect of barley and its amylopectin content on ruminal fermentation and nitrogen utilization in lactating dairy cows. J. Dairy Sci. 89:4321-4335

Granzin, B. C. 2003. Determining the optimum particle size of a maize grain supplement when fed to early lactation Holstein Friesian cows grazing temperate pastures. Final Report to Subtropical Dairy Program of Dairy Research and Development Corporation, QLD, AU.

Herrera-Saldana, R., R. Gomez-Alarcon, M. Torabi, and J. T. Huber. 1990. Influence of synchronizing protein and starch degradation in the rumen on nutrient utilization and microbial protein synthesis. J. Dairy Sci. 73:142-148.

Ipharraguerre, I. R., J. H. Clark, and D. E. Freeman. 2005a. Varying protein and starch in the diet of dairy cows. I. Effects on ruminal fermentation and intestinal supply of nutrients. J. Dairy Sci. $88: 2537-2555$

Ipharraguerre, I. R., J. H. Clark, and D. E. Freeman. 2005b. Rumen fermentation and intestinal supply of nutrients in dairy cows fed rumen-protected soy products. J. Dairy Sci. 88:2879-2892

Joy, M. T., E. J. DePeters, J. G. Fadel, and R. A. Zinn. 1997. Effects of corn processing on the site and extent of digestion in dairy cows. J. Dairy Sci. 80:2087-2097.

Knowlton, K. F., B. P. Glenn, and R. A. Erdman. 1998. Performance, ruminal fermentation, and site of starch digestion in early lactation cows fed corn grain harvested and processed differently. J. Dairy Sci. 81:1972-1984.

McCarthy, R. D. Jr., T. H. Klusmeyer, J. L. Vicini, J. H. Clark, and D. R. Nelson. 1989. Effects of source of protein and carbohydrate on ruminal fermentation and passage of nutrients to the small intestine of lactating cows. J. Dairy Sci. 72:2002-2016.
McNiven, M. A., M. R. Weisbjerg, and T. Hvelplund. 1995. Influence of roasting or sodium hydroxide treatment of barley on digestion in lactating cows. J. Dairy Sci. 78:1106-1115.

Moorby, J. M., R. J. Dewhurst, R. T. Evans, and J. L. Danelón. 2006. Effects of dairy cow diet forage proportion on duodenal nutrient supply and urinary purine derivative excretion. J. Dairy Sci. 89:3552-3562

Oba, M., and M. S. Allen. 2003. Effects of corn grain conservation method on ruminal digestion kinetics for lactating dairy cows at 2 dietary starch concentrations. J. Dairy Sci. 86:184-194.

Oliveira, J. S., J. T. Huber, J. M. Simas, C. B. Theurer, and R. S. Swingle. 1995. Effect of sorghum grain processing on site and extent of digestion of starch in lactating dairy cows. J. Dairy Sci. 78:1318-1327.

Overton, T. R., M. R. Cameron, J. P. Elliott, J. H. Clark, and D. R. Nelson. 1995. Ruminal fermentation and passage of nutrients to the duodenum of lactating cows fed mixture of corn and barley. J. Dairy Sci. 78:1981-1998.

Palmquist, D. L., M. R. Weisbjerg, and T. Hvelplund. 1993. Ruminal, intestinal, and total digestibilities of nutrients in cows fed diets high in fat and undegradable protein. J. Dairy Sci. 76:1353-1364.

Plascencia, A., and R. A. Zinn. 1996. Influence of flake density on the feeding value of steam-processed corn in diets for lactating cows. J. Anim. Sci. 74:310-316.

Poore, M. H., J. A. Moore, T. P. Eck, and C. B. Theurer. 1993. Effect of fiber source and ruminal starch degradability on site and extent of digestion in dairy cows. J. Dairy Sci. 76:2244-2253.

Qiu, X., M. L. Eastridge, and Z. Wang. 2003. Effects of corn silage hybrid and dietary concentration of forage NDF on digestibility and performance by dairy cows. J. Dairy Sci. 86:3667-3674.

Rémond, D., J. I. Cabrera-Estrada, M. Champion, B. Chauveau, R Coudure, and C. Poncet. 2004. Effect of corn particle size on site and extent of starch digestion in lactating dairy cows. J. Dairy Sci. 87:1389-1399.

Silveira, C., M. Oba, W. Z. Yang, and K. A. Beauchemin. 2007. Selection of barley grain affects ruminal fermentation, starch digestibility, and productivity of lactating dairy cows. J. Dairy Sci. 90:2860-2869.

Stensig, T., and P. H. Robinson. 1997. Digestion and passage kinetics of forage fiber in dairy cows as affected by fiber-free concentrate in the diet. J. Dairy Sci. 80:1339-1352.

Sutton, J. D., R. H. Phipps, D. E. Beever, D. J. Humphries, G. F. Hartnell, J. L. Vicini, and D. L. Hard. 2003. Effect of method of application of a fibrolytic enzyme product on digestive processes and milk production in Holstein-Friesian cows. J. Dairy Sci. $86: 546-556$.

Taylor, C. C., and M. S. Allen. 2005. Corn grain endosperm type and brown midrib 3 corn silage: Site of digestion and ruminal digestion kinetics in lactating cows. J. Dairy Sci. 88:1413-1424.

Ueda, K., A. Ferlay, J. Chabrot, J. J. Loor, Y. Chilliard, and M. Doreau. 2003. Effect of linseed oil supplementation on ruminal digestion in dairy cows fed diets with different forage:concentrate ratios. J. Dairy Sci. 86:3999-4007.

Van Vuuren, A. M., A. Klop, C. J. Van Der Koelen, and H. De Visser. 1999. Starch and stage of maturity of grass silage: Site of digestion and intestinal nutrient supply in dairy cows. J. Dairy Sci. $82: 143-152$

Van Vuuren, A. M., C. J. Van Der Koelen, and J. Vroons-De Bruin. 1993. Ryegrass versus corn starch or beet pulp fiber diet effects on digestion and intestinal amino acids in dairy cows. J. Dairy Sci. $76: 2692-2700$

Voelker, J. A., and M. S. Allen. 2003. Pelleted beet pulp substituted for high-moisture corn: 2. Effects on digestion and ruminal digestion kinetics in lactating dairy cows. J. Dairy Sci. 86:3553-3561.

Volden, H. 1999. Effects of level of feeding and ruminally undegraded protein on ruminal bacterial protein synthesis, escape of dietary protein, intestinal amino acid profile, and performance of dairy cows. J. Anim. Sci. 77:1905-1918.

Yang, W. Z., and K. A. Beauchemin. 2005. Effects of physically effective fiber on digestion and milk production by dairy cows fed diets based on corn silage. J. Dairy Sci. 88:1090-1098. 
Yang, W. Z., and K. A. Beauchemin. 2006. Increasing the physically effective fiber content of dairy cow diets may lower efficiency of feed use. J. Dairy Sci. 89:2694-2704.

Yang, W. Z., K. A. Beauchemin, K. M. Koenig, and L. M. Rode. 1997. Comparison of hull-less barley, barley, or corn for lactating cows: Effects on extent of digestion and milk production. J. Dairy Sci. 80:2475-2486.

Yang, W. Z., K. A. Beauchemin, and L. M. Rode. 1999. Effects of an enzyme feed additive on extent of digestion and milk production of lactating dairy cows. J. Dairy Sci. 82:391-403.

\section{APPENDIX 2. CALCULATION OF SIMPLE MEAN RUMINAL STARCH DEGRADATION}

As an example of simple mean RSDeg, consider the ration presented in Table A1 with a reported starch digestion of $60 \%$. Of the $5.22 \mathrm{~kg}$ of starch in the diet, $3.132 \mathrm{~kg}$ are degraded:

$$
5.22 \mathrm{~kg} \times 0.60 .
$$

The first assumption is that all feeds except the largest starch source are indigestible. Therefore, for this example, all $3.132 \mathrm{~kg}$ of degraded starch must come from the $4.900 \mathrm{~kg}$ of starch in corn grain. This means that the maximum possible degradation of corn grain is $63.9 \%$ :

$3.132 \mathrm{~kg}$ of starch degraded $/ 4.90 \mathrm{~kg}$ of starch

$$
\text { in corn grain } \times 100=63.9 \% \text {. }
$$

Table A1. Dairy cow ration with a reported starch digestion of $60 \%$

\begin{tabular}{lccc}
\hline Ingredient & $\begin{array}{c}\text { DMI, } \\
\mathrm{kg}\end{array}$ & $\begin{array}{c}\text { Starch, } \\
\%\end{array}$ & $\begin{array}{c}\text { Total, } \\
\mathrm{kg}\end{array}$ \\
\hline Alfalfa hay & 10.0 & 2.0 & 0.20 \\
Corn grain ground & 7.0 & 70.0 & 4.90 \\
Soybean meal & 2.0 & 6.0 & 0.12 \\
Wheat straw & 2.0 & 0.0 & 0.00 \\
Vitamin-mineral mix & 1.6 & & 0.00 \\
Total & 22.0 & & 5.22 \\
\hline
\end{tabular}

To find the minimum possible corn grain degradation, assume that all starch sources except the largest are $100 \%$ digestible. Thus the minimum of starch digestion for corn is

$3.132 \mathrm{~kg}$ of starch degraded - $(0.20 \mathrm{~kg}$ of alfalfa hay starch $+0.12 \mathrm{~kg}$ of soybean meal starch) $=2.812 \mathrm{~kg}$ of starch degraded from corn grain,

Minimum percent of starch degradability $=$ $2.812 \mathrm{~kg}$ of starch degraded/4.90 kg of corn starch $\times 100=57.4 \%$,

and the simple mean would be

$$
(63.9 \%+57.4 \%) / 2=60.6 \% .
$$

